\title{
Optimization of selected salts concentration for improved biohydrogen production from biodiesel-based glycerol using Enterobacter aerogenes
}

\author{
Rujira Jitrwung, Jonathan Verrett, Viviane Yargeau* \\ Department of Chemical Engineering, McGill University, 3610 University Street, Montreal, QC, Canada H3A 2B2
}

\section{A R T I C L E I N F O}

\section{Article history:}

Received 16 December 2011

Accepted 13 June 2012

Available online 24 July 2012

\section{Keywords:}

Enterobacter aerogenes

Glycerol

Biohydrogen

\begin{abstract}
A B S T R A C T
Enterobacter aerogenes have a known ability to convert glycerol (GL) in a fermentative process to yield hydrogen and ethanol as the main by-products. The concentration of some media constituents was optimized to maximize biohydrogen yield and rate of production. E. aerogenes were cultured in aerobic conditions, and then transferred into anaerobic conditions before being cultured in a minimum mineral synthetic media (MMSM) containing $15 \mathrm{~g} / \mathrm{L} \mathrm{GL}$. The concentration of selected salts were optimized in the following ranges: $0-300 \mathrm{mg} / \mathrm{L} \mathrm{MgSO}_{4}, 0-14 \mathrm{~g} / \mathrm{L} \mathrm{Na}_{2}$ EDTA, $0-10 \mathrm{mg} / \mathrm{L} \mathrm{CaCL} 2,0-10 \mathrm{~g} / \mathrm{L} \mathrm{Na}_{2} \mathrm{HPO}_{4}$, and 0 $-9.7 \mathrm{~g} / \mathrm{L} \mathrm{KH}_{2} \mathrm{PO}_{4}$. The results of the full factorial design indicated that the production of biohydrogen required a minimal concentration of $3.5 \mathrm{mg} / \mathrm{L}$ EDTA, $200 \mathrm{mg} / \mathrm{L} \mathrm{MgSO}_{4} \cdot 7 \mathrm{H}_{2} \mathrm{O}$ and no $\mathrm{CaCl}_{2} \cdot 2 \mathrm{H}_{2} \mathrm{O}$. A significant interaction between EDTA and $\mathrm{MgSO}_{4}$ was also observed. Results from the phosphate salts optimization showed that $\mathrm{Na}_{2} \mathrm{HPO}_{4}$ gave better results than $\mathrm{KH}_{2} \mathrm{PO}_{4}$. The optimal conditions determined using pure glycerol (commercial grade glycerol), were successfully applied to the fermentation of crude glycerol from biodiesel production. The results indicated promising yields of 0.79 and $0.84 \mathrm{~mol} / \mathrm{mol}$ of glycerol for bioethanol and biohydrogen, respectively, and this at a faster rate than reported previously for E. aerogenes.
\end{abstract}

(c) 2012 Elsevier Ltd. All rights reserved.

\section{Introduction}

Due to environmental concerns and increasing needs for alternative fuels, biodiesel has been increasingly produced over the past two decades for use as a diesel substitute and additive. Although biodiesel is a good candidate as alternative fuel, production costs have been increasing because of several factors such as increased price of alcohol used as raw material and decreased value of glycerol. Since glycerol (GL) is produced at a ratio of $10 \% \mathrm{wt}$ of the biodiesel produced, the market for crude glycerol has been relatively depressed because of a larger supply of crude glycerol than the ability to turn it into refined product. As a result, the value of crude glycerol on the market has been decreasing, which significantly impacts biodiesel production economics. This has encouraged the use of glycerol-containing waste as a substrate in fermentation processes to produce biohydrogen and other chemicals such as 1,3 propanediol, ethanol, lactic acid, and acetic acid [1-14]. Several studies have been performed on the anaerobic fermentation of glycerol into biohydrogen and bioethanol using different microorganisms. Studies have been performed using pure

\footnotetext{
* Corresponding author. Tel.: +1 514398 2273; fax: +1 5143986678.

E-mail address: viviane.yargeau@mcgill.ca (V. Yargeau).
}

species [1,2,4-7,13-17] and mixed cultures [11], including Klebsiella, Clostridium, Escherichia, and Enterobacter species. Klebsiella [1,15], Clostridium [2,3,6,7,13], and Escherichia [16] which typically convert glycerol into 1,3 propanediol, whereas Enterobacter aerogenes [4,17] was reported by Ito et al. 2005 [9], and Jitrwung and Yargeau 2010 [4] to convert glycerol into two main products, hydrogen and ethanol.

One of the studies using E. aerogenes to produce biohydrogen from crude glycerol produced through biodiesel manufacturing, was based on a packed bed reactor (PBR) using porous ceramics as a support material and a synthetic media composed of salts, yeast extract, and tryptone to support bacterial growth. The maximum $\mathrm{H}_{2}$ production rate and yield observed were $63 \mathrm{mmol} / \mathrm{l} / \mathrm{h}$ and $0.85 \mathrm{~mol} / \mathrm{mol} \mathrm{GL}$, respectively. Minor products such as 1,3 propanediol, pyruvic acid, lactic acid, acetic acid, and formic acid were also produced [4]. These experiments showed the potential of E. aerogenes grown in anaerobic conditions for the conversion of crude glycerol. However, this study and the others mentioned previously were using significant amount of costly additives such as salts, yeast extract and tryptone. Previous research has examined the effect of the concentration of some of the additives on bacterial growth, such as ammonium nitrate $\left(\mathrm{NH}_{4} \mathrm{NO}_{3}\right)$, ammonium chloride $\left(\mathrm{NH}_{4} \mathrm{Cl}\right)$, and sodium nitrate $\left(\mathrm{NaNO}_{3}\right)$. Results showed that $\mathrm{NH}_{4} \mathrm{Cl}$, $\mathrm{NH}_{4} \mathrm{NO}_{3}$, and $\mathrm{NaNO}_{3}$ supported $E$. aerogenes growth with optical 
densities $\left(\mathrm{OD}_{660}\right)$ of 7.0, 3.7, and 2.3 respectively. This growth was associated with a consumption of $\mathrm{NH}_{4}^{+}$with no residual $\mathrm{NO}_{3}^{-}$. Effect of iron ion $\left(\mathrm{Fe}^{2+}\right)$ concentration on hydrogen production from a starch solution $(15 \mathrm{~g} / \mathrm{L})$ was studied and optimal conditions of $\mathrm{pH}$ 7.0 to $8.0, \mathrm{Fe}^{2+}$ concentration of $10 \mathrm{mg} / \mathrm{L}$ and $\mathrm{NH}_{4} \mathrm{CO}_{3}$ concentration of $5.64 \mathrm{~g} / \mathrm{L}$ were determined [18]. The addition of a chelating agent such as EDTA (Ethylenediaminetetraacetic acid) or NTA (nitrilotriacetic acid), in combination with $\mathrm{Fe}^{2+}$, showed that EDTA enhanced $\mathrm{H}_{2}$ photoproduction by Rhodospirillum rubrum by inhibiting biosynthesis of hydrogen uptake hydrogenase and mobilization of iron [19]. Until now, most studies have used minimum mineral synthetic media (MMSM) containing 7 common salts $\left(\mathrm{Na}_{2} \mathrm{HPO}_{4}\right.$, $\mathrm{NH}_{4} \mathrm{NO}_{3}, \mathrm{FeSO}_{4} .7 \mathrm{H} 2 \mathrm{O} .7 \mathrm{H}_{2} \mathrm{O}, \mathrm{KH}_{2} \mathrm{PO}_{4}, \mathrm{MgSO}_{4} .7 \mathrm{H}_{2} \mathrm{O}, \mathrm{CaCl}_{2} .2 \mathrm{H}_{2} \mathrm{O}$, and $\mathrm{Na}_{2}$ EDTA). In our previous work using E. aerogenes [14] we reported optimized concentrations of three of these salts $\left(6 \mathrm{~g} / \mathrm{L} \mathrm{Na}_{2} \mathrm{HPO}_{4}\right.$, $1.5 \mathrm{~g} / \mathrm{L} \mathrm{NH}_{4} \mathrm{NO}_{3}, 6.25 \mathrm{mg} / \mathrm{L} \mathrm{FeSO}_{4}$ ) along with an optimal inoculum volume ratio of $18 \%$ and oxygen concentration in the inoculation step of $7.5 \% \mathrm{O}_{2}$. These conditions used with commonly used concentrations of the other salts $\left(4 \mathrm{~g} / \mathrm{L} \mathrm{KH}_{2} \mathrm{PO}_{4}, 200 \mathrm{mg} / \mathrm{L} \mathrm{MgSO}_{4}\right.$, $10 \mathrm{mg} / \mathrm{L} \mathrm{CaCl} 2,14 \mathrm{mg} / \mathrm{L} \mathrm{Na}{ }_{2}$ EDTA and $15 \mathrm{~g} / \mathrm{L}$ of glycerol), resulted in hydrogen yields of 0.68 and $0.85 \mathrm{~mol} \mathrm{H}_{2} / \mathrm{mol}$ glycerol for pure and crude glycerol, respectively [14].

The objective of the study presented here was to optimized the concentration of the other four salts commonly used $\left(\mathrm{KH}_{2} \mathrm{PO}_{4}\right.$, $\mathrm{MgSO}_{4} \cdot 7 \mathrm{H}_{2} \mathrm{O}, \mathrm{CaCl}_{2} \cdot 2 \mathrm{H}_{2} \mathrm{O}$, and $\mathrm{Na}_{2} \mathrm{EDTA}$ ) and the research hypotheses were: 1 ) EDTA acts as an inhibitor at high concentration and using excess EDTA results in a lower production rate; 2) concentration of salts such as $\mathrm{CaCl}_{2}, \mathrm{MgSO}_{4}$ and $\mathrm{Na}_{2} \mathrm{HPO}_{4} / \mathrm{KH}_{2} \mathrm{PO}_{4}$ can be optimized to improve hydrogen production and lower operating costs, and 3) conditions optimized for pure glycerol conversion apply to crude glycerol fermentation. The experiments described in the following sections were designed to confirm or refute these hypotheses.

\section{Materials and methods}

\subsection{Microorganism and inoculums preparation}

E. aerogenes (ATCC 35029), obtained from the American Type Culture Collection (ATCC) was started under aerobic conditions in $100 \mathrm{~mL}$ of nutrient broth BD 234000 from Becton and Dickinson Company ( $12 \mathrm{~g} / \mathrm{L})$. Cultures were incubated for a period of $20-24 \mathrm{~h}$, at $37{ }^{\circ} \mathrm{C}$ and $120 \mathrm{rpm}$, to reach the stationary phase, $10 \mathrm{~mL}$ were used as inoculum. $190 \mathrm{~mL}$ of the same nutrient broth was placed in $250-\mathrm{mL}$ serum bottles which were then heated at $50{ }^{\circ} \mathrm{C}$ to ensure dissolution of the compounds, and then cooling down to $25{ }^{\circ} \mathrm{C}$ before capping of the bottles to create a static oxygen condition. $10-\mathrm{mL}$ inoculums were then transferred into the $250-\mathrm{mL}$ serum bottles containing $190 \mathrm{~mL}$ of the same nutrient broth. Following the inoculation, the serum bottles were incubated at $37{ }^{\circ} \mathrm{C}, 120 \mathrm{rpm}$ for $20-24 \mathrm{~h}$ until stationary phase was reached.

\subsection{Minimum mineral synthetic media (MMSM) and glycerol concentration}

The following compounds were added per litre of deionised water to prepare the MMSM at a $\mathrm{pH}$ of 6.8: ammonium nitrate $\left(\mathrm{NH}_{4} \mathrm{NO}_{3}: 1.5 \mathrm{~g}\right)$, ferrous sulfate heptahydrate $\left(\mathrm{FeSO}_{4} .7 \mathrm{H}_{2} \mathrm{O}\right.$ : $0.00625 \mathrm{~g})$, mono potassium phosphate $\left(\mathrm{KH}_{2} \mathrm{PO}_{4}: 0-9.749 \mathrm{~g}\right)$, disodium hydrogen phosphate $\left(\mathrm{Na}_{2} \mathrm{HPO}_{4}: 0-12.2 \mathrm{~g}\right)$, magnesium sulfate heptahydrate $\left(\mathrm{MgSO}_{4} .7 \mathrm{H}_{2} \mathrm{O}: 0-0.300 \mathrm{~g}\right)$, calcium chloride $\left(\mathrm{CaCl}_{2}\right.$ : $\left.\quad 0-0.015 \mathrm{~g}\right)$ obtained from Sigma Aldrich, tetraethylenediamine disodium salts ( $\mathrm{Na}_{2}$ EDTA: $0-0.014 \mathrm{~g}$ ) obtained from Fisher Scientific and either $15 \mathrm{~g} / \mathrm{L}$ of pure glycerol (PG) obtained from Sigma Aldrich or $18.5 \mathrm{~g} / \mathrm{L}$ crude glycerol (CG) obtained from Rothsay Biodiesel, Canada. The media was boiled in 125-mL serum bottles for $20 \mathrm{~min}$, warmed for $5 \mathrm{~min}$, and then cooled down on ice for 5 min with a continuous flushing of argon in the headspace to remove oxygen prior to capping the bottles (referred to as the experiment bottles).

\subsection{Biohydrogen production experiments}

Following the preparation of the glycerol-containing MMSM (Section 2.2) and inoculums bottles (Section 2.1), experiments were started. Prior to taking inoculum from the inoculum bottles, an argon-oxygen gas mixture $\left(7.5 \% \mathrm{O}_{2}\right)$ was used to over-pressurize the inoculum bottles while maintaining the semi anaerobic conditions identified in previous work [14] has being beneficial to the production of hydrogen by $E$. aerogenes. $9.4 \mathrm{~mL}$ of inoculum was then transferred from an inoculum bottle into the experiment bottles containing $50 \mathrm{~mL}$ of glycerol-containing MMSM. The transfer was done following the Hungate technique [20], using an aseptic syringe. The experiment bottles were incubated at $37^{\circ} \mathrm{C}$ and $120 \mathrm{rpm}$ until hydrogen production ceased. Each conditions tested was run using two replicates and only the averages are reported.

The experiments were performed in three different phases including pre-screening experiments and a full factorial design to determine the optimal concentration of three selected salts, $\mathrm{MgSO}_{4} \cdot 7 \mathrm{H}_{2} \mathrm{O}, \mathrm{CaCl}_{2} \cdot 2 \mathrm{H}_{2} \mathrm{O}$, and $\mathrm{Na}_{2}$ EDTA (Optimization I, see Section 2.3.1), an optimization of the ratio of $\mathrm{Na}_{2} \mathrm{HPO}_{4}(\mathrm{PH})$ and $\mathrm{KH}_{2} \mathrm{PO}_{4}$ (KP) while maintaining the amount of phosphate $\left(\mathrm{PO}_{4}^{3-}\right)$ constant (Optimization II, see Section 2.3.2) and lastly, the application of the optimized conditions to the crude glycerol which consisted in the comparison of the results obtained using pure and crude glycerol (Application to crude glycerol, see Section 2.3.3).

\subsubsection{Optimization I: concentration of $M G, C A$, and $E D$}

Preliminary experiments were performed to determine the optimal ranges of concentration to be used. The screening of salts was done by varying the concentration of MG and CA by $50 \%$ above and below the concentrations reported in literature (MG $200 \mathrm{mg} / \mathrm{L}$, CA $10 \mathrm{mg} / \mathrm{L}$ [14]), and including a concentration of $0 \mathrm{mg} / \mathrm{L}$. The concentrations studied were $0,100,200,300 \mathrm{mg} / \mathrm{L}$ for MG and 0, 5, $10,15 \mathrm{mg} / \mathrm{L}$ for CA. ED concentration was varied in order to obtain four concentrations below the value reported in literature (ED $14 \mathrm{mg} / \mathrm{L}$ [8]): 0, 3.5, 7.0, 10.5, and $14 \mathrm{mg} / \mathrm{L}$.

A full factorial design was then used to determine the optimal concentrations of MG, CA and ED in the most favourable ranges identified in the screening step. A two levels factorial design including a middle point was set up. The three salts were tested at the low concentration of $0 \mathrm{mg} / \mathrm{L}$, middle points of $1.75,100$ and $5 \mathrm{mg} / \mathrm{L}$ and high concentrations of at 3.50, 200, and $10 \mathrm{mg} / \mathrm{L}$ for ED, $\mathrm{MG}$, and CA respectively.

\subsubsection{Optimization II: ratio of $\mathrm{Na}_{2} \mathrm{HPO}_{4}$ to $\mathrm{KH}_{2} \mathrm{PO}_{4}$}

In order to study the effect of two phosphate salts commonly used as buffer, potassium and sodium salts, experiments were performed by maintaining a constant molar amount of phosphate equivalent to the level used in previous studies $\left(8.0 \mathrm{~g} / \mathrm{L} \mathrm{Na}_{2} \mathrm{HPO}_{4}\right.$ and $4.0 \mathrm{~g} / \mathrm{L} \mathrm{KH}_{2} \mathrm{PO}_{4}$ [14]), while varying the ratio of $\mathrm{Na}_{2} \mathrm{HPO}_{4}(\mathrm{PH})$ to $\mathrm{KH}_{2} \mathrm{PO}_{4}(\mathrm{KP})$. The levels of $\mathrm{PH}$ and $\mathrm{KP}$ were adjusted to obtain five different mass ratios $\mathrm{PH} / \mathrm{KP}$ : 0 (PH only), 0.43, 0.67, 0.84 and 1 (KP only). For each ratio tested, the $\mathrm{pH}$ was adjusted to 6.8 using either $10 \%$ potassium hydroxide or $10 \%$ phosphoric acid.

\subsubsection{Application of the optimized conditions to crude glycerol}

The optimized conditions obtained from previous work [14] and through the optimization studies described in the earlier sections (Sections 2.3.1 and 2.3.2) were used to study the conversion of 


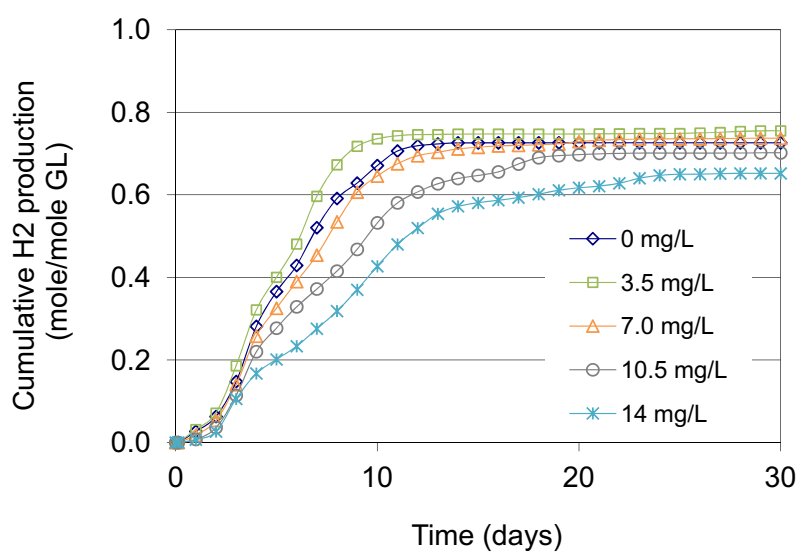

Fig. 1. Hydrogen production using various concentrations of $\mathrm{Na}_{2}$ EDTA under fixed levels of $200 \mathrm{mg} / \mathrm{L} \mathrm{MgSO}_{4}$ and $100 \mathrm{mg} / \mathrm{L} \mathrm{CaCl}_{2}$.

crude glycerol obtained from a biodiesel production company. Crude glycerol was vacuum filtered using filter paper P8 and P4 purchased from Fisher Scientific before being mixed with deionized water in order to obtain a concentration of $18.5 \mathrm{~g} / \mathrm{L}$ of crude glycerol (corresponding to $15 \mathrm{~g} / \mathrm{L}$ of glycerol). The $\mathrm{pH}$ was adjusted to 6.8 using $10 \%$ phosphoric acid.

\subsection{Analytical methods}

The volume of biogas produced was measured every $24 \mathrm{~h}$ using a gas tight syringe. Biogas samples were analysed by gas chromatography to determine hydrogen concentration. A Hewlett Packard 5890 gas chromatograph equipped with a molecular sieve column $8 \mathrm{~A}$ maintained at a temperature of $80^{\circ} \mathrm{C}$, using $3.0 \mathrm{~mL} / \mathrm{min}$ argon as a carrier gas, and a thermal conductivity detector (TCD) was used. When hydrogen production ceased, samples of liquid were collected to characterize the residual solution composition. The liquid samples were centrifuged at $10,000 \mathrm{rpm}$ for $10 \mathrm{~min}$, and the supernatant was collected for liquid chromatography and ion chromatography analysis. A Hewlett Packard 1050 HighPerformance Liquid Chromatograph (HPLC) equipped with a Rezex ROA-Organic Acid $\mathrm{H}^{+} 8 \% 150 \times 7.80 \mathrm{~mm}$ column and a refractive index detector (RI) HP1047A was used to measure the concentration of glycerol, 1,3 propanediol, 1-propanol, methanol, pyruvate, lactate, acetate, formate, and ethanol. The mobile phase was $0.035 \mathrm{M} \mathrm{H}_{2} \mathrm{SO}_{4}$ at a flow rate of $0.8 \mathrm{~mL} / \mathrm{min}$. The column temperature was $65{ }^{\circ} \mathrm{C}$ and the temperature of the RI was $50{ }^{\circ} \mathrm{C}$. Inorganic ions such as nitrite, nitrate, sulfate, and phosphate were monitored using an Ion Chromatograph (IC) from Metrohm, model 820 IC, equipped with a Metrosep A supp7 250/4.0 mm-5 $\mu \mathrm{m}$ column maintained at $45{ }^{\circ} \mathrm{C}$ and a conductivity detector and using $3 \mathrm{~mm} \mathrm{Na}_{2} \mathrm{CO}_{3}$ as a mobile phase.

Table 1

ANOVA results.

\begin{tabular}{llccl}
\hline Term & $\begin{array}{l}\text { Sum of } \\
\text { squares }\end{array}$ & $\begin{array}{l}\text { Degree of } \\
\text { freedom }\end{array}$ & F-value & $\begin{array}{l}P \text {-value } \\
\text { Prob }>F\end{array}$ \\
\hline $\mathrm{CaCl}_{2}$ & 0.00004 & 1 & 0.04 & 0.8414 \\
$\mathrm{MgSO}_{4}$ & 0.01248 & 1 & 13.77 & 0.004 \\
$\mathrm{EDTA}$ & 0.00074 & 1 & 0.81 & 0.388 \\
$\mathrm{CaCl}_{2} \cdot \mathrm{MgSO}_{4}$ & 0.00112 & 1 & 1.23 & 0.293 \\
$\mathrm{CaCl}_{2} \cdot$ EDTA & 0 & 0 & 0 & 0.9972 \\
$\mathrm{MgSO}_{4} \cdot$ EDTA & 0.00802 & 1 & 8.85 & 0.0139 \\
Error & 0.00906 & 10 & & \\
Total & 0.03145 & 17 & & \\
\hline
\end{tabular}

\subsection{Statistical methods}

The optimization of the concentration of the three salts was performed in a full factorial design with middle point. Each condition was performed in duplicate (2 Blocks), and the middle point was added to verify the performance of the model. For predicting the optimal concentrations based on the main and interaction effects, the Software SAS 9.2 obtained from the company SAS was used to fit the first-order regression model as follows:

$Y=b_{0}+\sum b_{i} X_{i}+\sum b_{i j} X_{i} X_{j}$

where $Y=$ hydrogen yield; $X_{i}(i=1,2,3)$ are the coded variables that represent the concentrations of $\mathrm{ED}, \mathrm{MG}$, and CA respectively; $b_{j}$ $(j=1,2,3)$ are the regression coefficients; $b_{i j}$ are the interaction terms.

\section{Results and discussion}

\subsection{Preliminary experiments to determine range of salts concentration}

Results showed that in the range of $0 \mathrm{mg} / \mathrm{L}-300 \mathrm{mg} / \mathrm{L}, \mathrm{MgSO}_{4}$ (MG) did not have any significant effects on lag phase, production rate, and hydrogen yield (data not shown). For $\mathrm{CaCl}_{2}$ (CA), over the range of $0 \mathrm{mg} / \mathrm{L}$ to $15 \mathrm{mg} / \mathrm{L}$ studied, no significant changes in the lag phase, production rate, and hydrogen yield were observed (data not shown). Results indicated that in the range studied of $0 \mathrm{mg} / \mathrm{L}$ to $14 \mathrm{mg} / \mathrm{L}, \mathrm{Na}_{2}$ EDTA (ED) had a significant effect on hydrogen production rate and yield, as can be seen in Fig. 1. The average production rates, calculated over the exponential phase, decreased from $0.088 \mathrm{~mol} / \mathrm{mol} \mathrm{GL} /$ day at $0 \mathrm{mg} \mathrm{ED} / \mathrm{L}$ to $0.042 \mathrm{~mol} / \mathrm{mol} \mathrm{GL} /$ day at $14.0 \mathrm{mg} / \mathrm{L}$. The maximum rate of production and hydrogen yield were observed at a concentration of ED of $3.5 \mathrm{mg} / \mathrm{L}$. Kern et al. 1992 [10] showed that the addition of $0.5 \mathrm{~mm}(146 \mathrm{mg} / \mathrm{L})$ EDTA supported the growth of $R$. rubrum and increased the $\mathrm{H}_{2}$ production by three folds. The optimal concentration observed here is much lower, indicating that the optimal amount of $\mathrm{Na}_{2}$ EDTA might be strain dependent.

The results of the preliminary experiments seem to indicate that only ED would affect hydrogen production over the ranges studied. However, when considering the inhibition effect of ED observed at the high concentration of ED used when studying the individual effects of MG and CA on hydrogen production, we hypothesized that the inhibition effect of ED may have interfered with the MG and CA results. Ranges of $0-200 \mathrm{mg} / \mathrm{L}$ for $\mathrm{MG}, 0-10 \mathrm{mg} / \mathrm{L}$ for CA

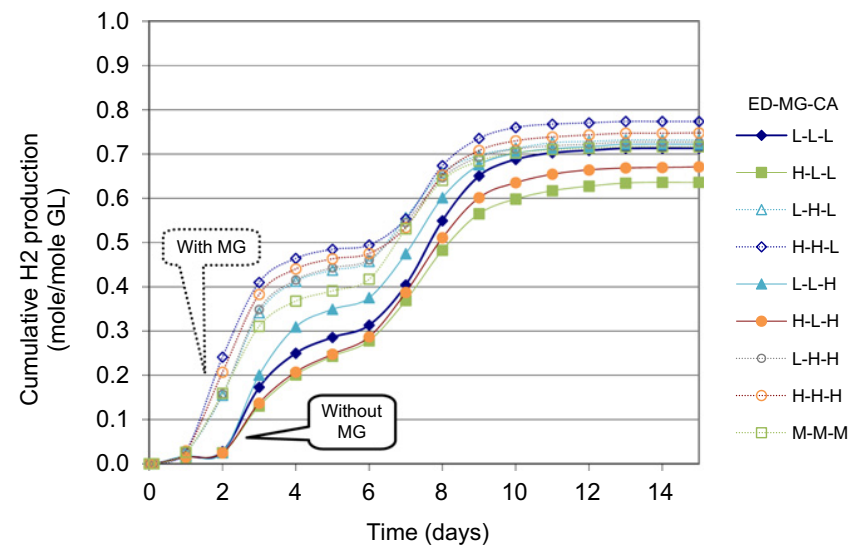

Fig. 2. Comparison of results of the full factorial design obtained at the various combinations of the low (L), medium (M) and high (H) levels of ED-MG-CA. 


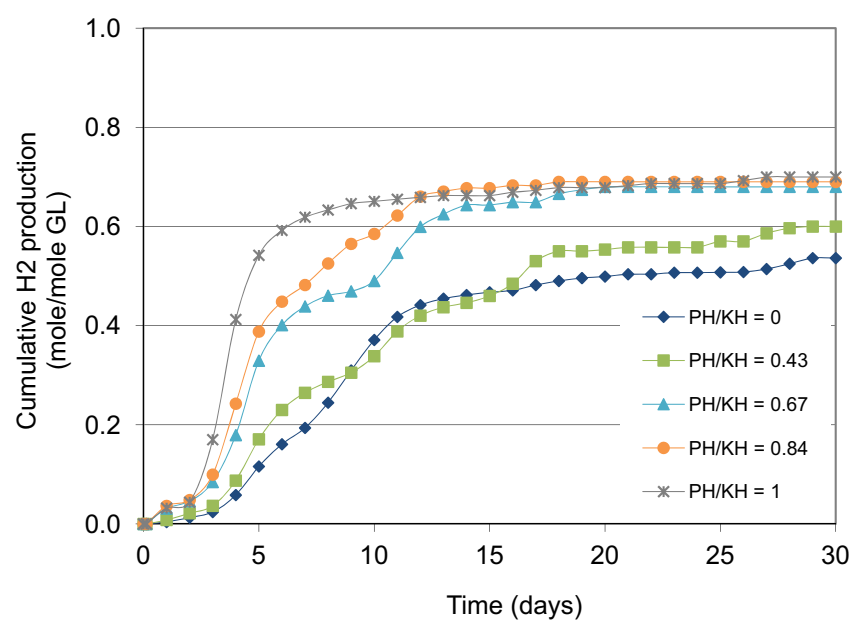

Fig. 3. Comparison the effect of the amounts of $\mathrm{Na}_{2} \mathrm{HPO}_{4}(\mathrm{PH})$ and $\mathrm{KH}_{2} \mathrm{PO}_{4}(\mathrm{KP})$ in pure glycerol tested at various mass ratios $\mathrm{PH} / \mathrm{KP}$.

and $0-3.5 \mathrm{mg} / \mathrm{L}$ for ED were thus selected to perform the full factorial design allowing to study the main effects and the interaction effects of these three salts, as presented in the following section.

\subsection{Optimization of concentration of salts}

The results of the 9 runs with 2 replicates (blocks) of the factorial design were analysed using the software SAS 9.2 for the main effects and interaction effects of the three salts. The results of the two-way ANOVA are presented in Table 1. Amongst the three trace salts studied, only MG had a $P$-value less than 0.1 indicating a significant effect on hydrogen production. The results for MG are similar to those reported by Alshiyab et al. 2008 which indicated that $\mathrm{FeSO}_{4} .7 \mathrm{H}_{2} \mathrm{O}, \mathrm{MgSO}_{4} .7 \mathrm{H}_{2} \mathrm{O}$, and $\mathrm{CaCl}_{2} .2 \mathrm{H}_{2} \mathrm{O}$ are all required for the production of biohydrogen by Clostridium acetobutylicum (NCIMB 13357) growing on glucose (5 g/L) [1]. On the contrary, the concentration of $\mathrm{CaCl}_{2} \cdot 2 \mathrm{H}_{2} \mathrm{O}$ had no significant effect on hydrogen yield indicating again that the optimal concentrations seem to be highly dependent on the biological system used.

As hypothesized, a significant interaction effect $(P<0.05)$ was found between ED and MG, as shown in Table 1. The interaction of $\mathrm{ED}$ and MG can be explained by the different mechanisms of action of each compound in the metabolic conversion of glycerol by $E$. aerogenes. It can be hypothesize that MG is needed to supply $\mathrm{Mg}^{2+}$ (Magnesium ion) for growth rather than for hydrogen production. This hypothesis is supported by results reported by Alshiyab et al.

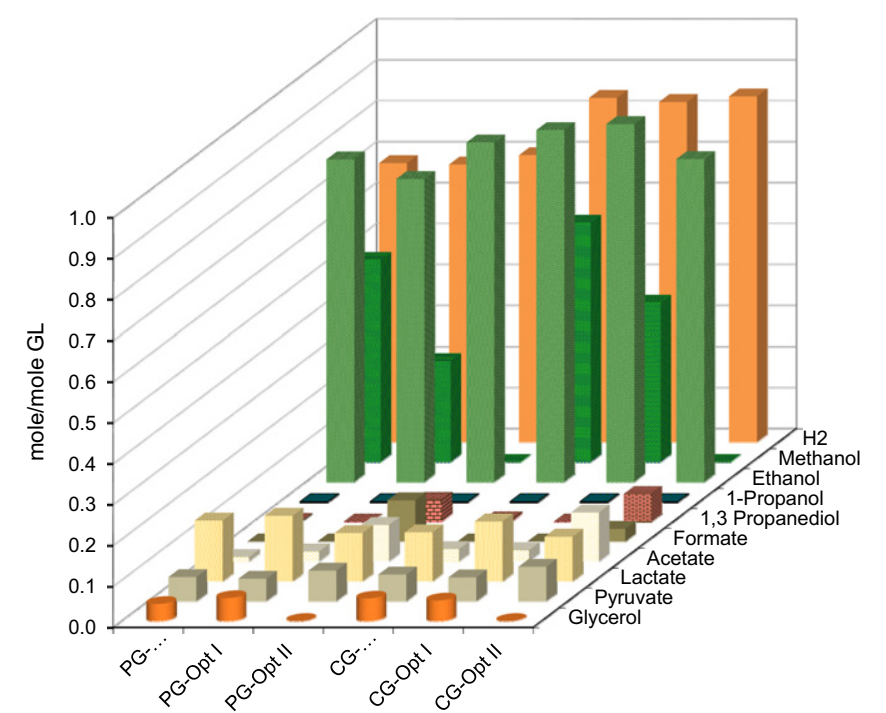

Fig. 5. Comparison of products formed using the reference conditions and the two sets of optimized conditions for the conversion of pure glycerol (PG) and crude glycerol (CG).

2008 [1] which indicated that an increase in the concentration of $\mathrm{MgSO}_{4} .7 \mathrm{H}_{2} \mathrm{O}$ did not significantly increase hydrogen production but increased glucose consumption from $87 \%$ to $98 \% . \mathrm{Mg}^{2+}$ may in the same way help in decreasing the lag phase, as observed in Fig. 2, which shows that the 4 combinations using high level of MG yielded a shorter lag phase than the 4 combinations without MG.

\subsection{Optimization of phosphate buffer}

Results presented in Fig. 3 showed that KP was not essential to E. aerogenes for hydrogen production while the amount of $\mathrm{PH}$ greatly affected the lag phase, production rate and yield. Results showed that increasing $\mathrm{Na}_{2} \mathrm{HPO}_{4}(\mathrm{PH})$ reduced the lag phase duration time from 3 to 2 days and increased rate of hydrogen production from 0.020 to $0.166 \mathrm{~mol} \mathrm{H}_{2} / \mathrm{mol} \mathrm{GL} /$ day.

\subsection{Application of optimized conditions to crude glycerol}

The reference conditions reported in our previous work [14] and the two sets of optimized conditions obtained in the previous sections using pure glycerol were tested for the conversion of crude glycerol ( $18.5 \mathrm{~g} / \mathrm{L}$, equivalent to $15 \mathrm{~g} / \mathrm{L} \mathrm{GL}$ ) into hydrogen. To facilitate comparison, results obtained for pure and crude glycerol are presented in Fig. 4a and b, respectively. By comparing results
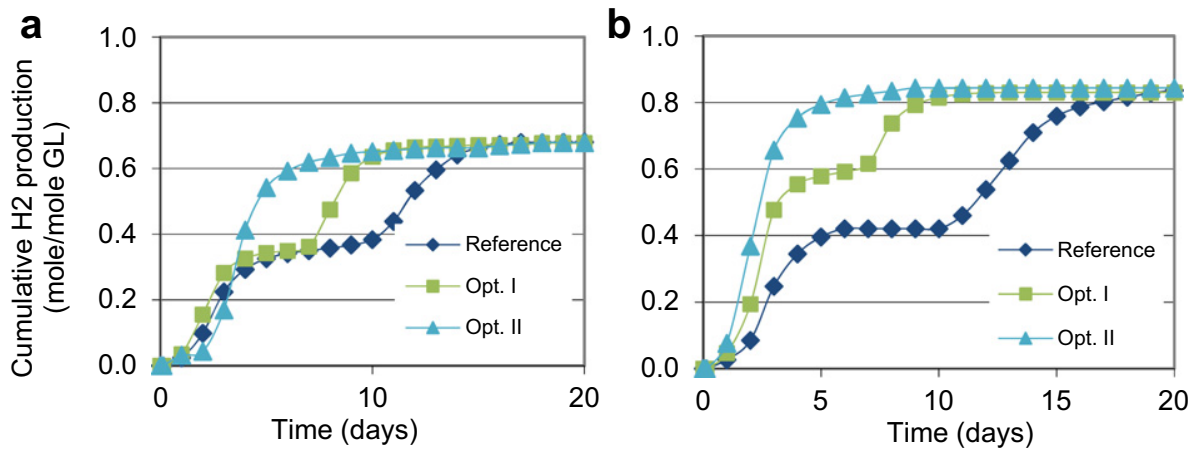

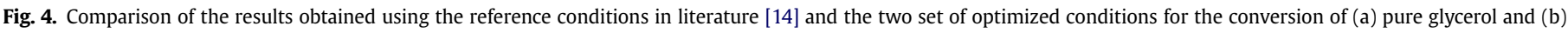
crude glycerol. 
obtained in Optimization I (squares) to the reference conditions (diamonds), it is noted that optimizing the concentration of $\mathrm{Na}_{2}$ EDTA and $\mathrm{MgSO}_{4}$ significantly reduced the second lag phase from 7 days to 4 days for both PG and CG. When comparing Optimization II (triangles) with Optimization I (squares), the results confirmed that while $\mathrm{KH}_{2} \mathrm{PO}_{4}$ was not needed, $\mathrm{Na}_{2} \mathrm{HPO}_{4}$ significantly increased the rate of production by preventing the second lag phase. The disappearance of the diauxic growth pattern following the optimization of the salts concentrations is still unexplained and a more thorough study of this phenomenon would be interesting. The results also indicated that CG (Fig. 4b) yielded better hydrogen yield and rate of production than pure glycerol (Fig. 4a) suggesting that other compounds present in crude glycerol supported the conversion of glycerol and the production of biohydrogen.

Fig. 5 presents results of the gas and liquid analysis and confirm that the main products formed are hydrogen and ethanol, as reported in Jitrwung and Yargeau [14], Seifert et al. [15], and Ito et al. [4]. These also indicate an almost complete conversion glycerol (residual concentration below the limit of detection) when using the conditions determined in Optimization II, for both PG and CG.

\section{Conclusion}

The three hypotheses of the studies were confirmed and the optimization of salts concentrations not only enhanced the hydrogen production but also decreased the salts requirements, leading to lower operating costs. The yields of biohydrogen and bioethanol, which were obtained using the optimized conditions for CG were approximately 0.84 and $0.79 \mathrm{~mol} / \mathrm{mol} \mathrm{GL}$, respectively. Comparing with Seifert et al., 2009 [21] reporting $0.41 \mathrm{~mol} \mathrm{H}_{2} / \mathrm{mol}$ GL for a range of glycerol concentration of 5-30 g/L, Jitrwung and Yargeau 2011 [14] reporting the production of $0.85 \mathrm{~mol} / \mathrm{mol} \mathrm{GL}$ over 14 days after 2 days of lag phase, this optimization resulted in an equal or higher conversion, shorter lag phases and higher production rate. This study further demonstrates the potential of producing biohydrogen and bioethanol from crude glycerol produced through biodiesel manufacturing by $E$. aerogenes. However, challenges remain to scale-up and transfer these results to a continuous mode of operation required for industrial application.

\section{Acknowledgement}

This work was partly funded by Thailand Institute of Scientific and Technological Research and the Fonds de Recherche Nature et Technologies du Québec. Thanks to Andrew Golsztajn and Ranjan Roy for their analytical support.

\section{References}

[1] Liu F, Fang B. Optimization of bio-hydrogen production from biodiesel wastes by klebsiella pneumoniae. Biotech J 2007;2(3):374-80.

[2] González-Pajuelo M, Meynial-Salles I, Mendes F, Andrade JC, Vasconcelos I, Soucaille P. Metabolic engineering of clostridium acetobutylicum for the industrial production of 1,3-propanediol from glycerol. Metab Eng 2005; 7(5-6):329-36

[3] Biebl H. Fermentation of glycerol by clostridium pasteurianum-batch and continuous culture studies. J Ind Microbiol Biot 2001;27:18-26.

[4] Ito T, Nakashimada Y, Senba K, Matsui T, Nishio N. Hydrogen and ethanol production from glycerol-containing wastes discharged after biodiesel manufacturing process. Biosci Eng 2005;100(3):260-5.

[5] Willke T, Vorlop K. Biotransformation of glycerol into 1,3-propanediol. Eur J Lipid Sci Tech 2008;110(9):831-40.

[6] Taconi KA, Venkataramanan KP, Johnson DT. Growth and solvent production by clostridium pasteurianum atccvvr 6013tm utilizing biodiesel-derived crude glycerol as the sole carbon source. Environ Prog Sust Energ 2009; 28(1):100-10.

[7] Saint-Amans S, Perlot P, Goma G, Soucaille P. High production of 1,3propanediol from glycerol by clostridium butyricum vpi 3266 in a simply controlled fed-batch system. Biotechnol Lett 1994;16(8):831-6.

[8] Barbirato F, Himmi EH, Conte T, Bories A. 1,3-propanediol production by fermentation: an interesting way to valorize glycerin from the ester and ethanol industries. Ind Crop Prod 1998;7(2-3):281-9.

[9] Yazdani SS, Gonzalez R. Anaerobic fermentation of glycerol: a path to economic viability for the biofuels industry. Curr Opin Biotech 2007;18(3): 213-9.

[10] Wittlich P, Themann A, Vorlop K-D. Conversion of glycerol to 1,3propanediol by a newly isolated thermophilic strain. Biotechnol Lett 2001; 23(6):463-6.

[11] Temudo MF, Poldermans R, Kleerebezem R, VanLoosdrecht MCM. Glycerol fermentation by (open) mixed cultures: a chemostat study. Biotechnol Bioeng 2008;100(6):1088-98.

[12] Selembo PA, Perez JM, Lloyd WA, Logan BE. Enhanced hydrogen and 1,3propanediol production from glycerol by fermentation using mixed cultures. Biotechnol Bioeng 2009;104(6):1098-106.

[13] Biebl H. Glycerol fermentation of 1,3-propanediol by clostridium butyricum. Measurement of product inhibition by use of a ph-auxostat. Appl Microbiol Biot 1991;35(6):701-5.

[14] Jirtwung R, Yargeau V. Optimization of media composition for the production of biohydrogen from waste glycerol. Int J Hydrogen Energ 2011;36:9602-11.

[15] Solomon BO, Zeng AP, Biebl H, Ejiofor AO, Posten C, Deckwer WD. Effects of substrate limitation on product distribution and h2/co2 ratio in klebsiella pnuemoniae during anaerobic fermentation of glycerol. Appl Microbiol Biot 1994;42:222-6.

[16] Gonzalez R, Murarka A, Dharmadi Y, Yazdani SS. A new model for the anaerobic fermentation of glycerol in enteric bacteria: trunk and auxiliary pathways in Escherichia coli. Metab Eng 2008;10(5):234-45.

[17] Sakai S, Yagishita T. Microbial production of hydrogen and ethanol from glycerol-containing wastes discharged from a biodiesel fuel production plant in a bioelectrochemical reactor with thionine. Biotechnol Bioeng 2007;98(2): 340-8.

[18] Liu G, Shen J. Effects of culture and medium conditions on hydrogen production from starch using anaerobic bacteria. Biosci Eng 2004;98(4): 251-6.

[19] Kern M, Koch H-G, Klemme J-H. Edta activation of h2 photoproduction by rhodospirillum rubrum. Appl Microbiol Biot 1992;37(4):496-500.

[20] Miller TL, Wolin MJ. A serum bottle modification of the hungate technique for cultivating obligate anaerobes. Appl Microbiol Biot 1974;27(5):985-7.

[21] Seifert K, Waligorska M, Wojtowski M, Laniecki M. Hydrogen generation from glycerol in batch fermentation process. Int J Hydrogen Energ 2009;34(9): $3671-8$. 